\title{
Environmental, Personality and Motivational Factors: A Comparison Study between Women Entrepreneurs and Women Non Entrepreneurs in Malaysia
}

\author{
Kavitha Raman ${ }^{1}$, R. N. Anantharaman ${ }^{1} \&$ Santhi Ramanathan ${ }^{1}$ \\ ${ }^{1}$ Faculty of Business, Multimedia University, Malaysia \\ Correspondence: Kavitha Raman, Faculty of Business, Multimedia University, Jalan Ayer Keroh Lama, 75450 \\ Melakaa, Malaysia. E-mail: kavitha.raman@mmu.edu.my
}

Received: January 31, 2013

Accepted: April 8, 2013

Online Published: June 17, 2013

doi:10.5539/ijbm.v8n13p15

URL: http://dx.doi.org/10.5539/ijbm.v8n13p15

\begin{abstract}
Entreprenership has been observed as one of the important factors that help to lift the economy of a nation. Due to the fact that women play an equal role in the development of a country, this study aims to identify the environmental, personality and motivational factors that may lead to entrepreneurial decision. A comparison of these three factors is studied among women entrepreneurs in Small and Medium Enterprises (SMEs) with women non-entrepreneurs. A thorough literature had been reviewed to understand the entrepreneurial decision among women. This study is based on a questionnaire survey and the results indicate that there is a significant difference in environmental, personality and motivational factors among women entrepreneurs and non-entrepreneurs. The environmental factors found psychological support, benefit from environment, and previous work condition as significant predictors of women entreprenuership while the nine significant personality differences observed in this study are that the entrepreneurs portray more reasoning skills, emotional stability, vigilance and abstractness. Apart from that, entrepreneurs are also found to have more privateness, high openness to change, perfectionism, more tension and less liveliness. Finally for motivation factors, results revealed that individual core is not a significant predictor of women entreprenuership.
\end{abstract}

Keywords: environmental factors, personality, motivation, women entrepreneurs, SMEs

\section{Introduction}

Entrepreneurship has significantly become an important indicator of the economic development. Many researchers and economists around the globe have regarded entrepreneurship as the driving force of economic growth of a country (Schumpeter, 1934; Kent at.el., 1982; Kidane \& Harvey, 2009; Nafukho \& Muyia, 2010). Remarkably, entrepreneurship has become synonymous with creation, innovation, economic development and more. Consistent with its growth, interest in studying women's issues connected with entrepreneurial activity has also emerged.

Many developing countries including Malaysia are actively promoting women entrepreneurship as a way of accelerating economic development. The government seriously comprehends and recognizes the role of women entrepreneurs as the moving force in achieving Malaysia's Vision 2020. The participation of women entrepreneurs in small and medium enterprises (SMEs) has increased from $18.0 \%$ in 2000 to $27.8 \%$ in 2003 (Normah 2006). These women were mainly working proprietors and active business partners. In line with this, the Malaysian Small and Medium Industries Development Corporation or known as SMIDEC has allocated a special assistance scheme worth RM9.2 million for women entrepreneurs in 2006. Eventually, there has been a steady increase in women participation in the creation of new enterprises in this country (Normah 2006).

As Malaysia comprehends and recognizes the role of women entrepreneurs as the moving force in achieving Malaysia's Vision 2020, the government, through the establishment of the Ministry of Women, Family and Community Development (MWFCD) in 2001 and the formation of the Cabinet Committee on Gender Equality in 2004 provides greater support to women's participation in the country's development. The establishment of women entrepreneurs associations such as the Federation of Women Entrepreneurs Association Malaysia (FEM), National Association of Women Entrepreneurs of Malaysia (NAWEM), Persatuan Usahawan Wanita Bumiputera (USAHANITA), the Women's Wing of the Malay Chamber of Commerce Malaysia of the State of Selangor and 
many more is a clear evidence on the commitment shown by the government to encourage more Malaysian women to become entrepreneurs.

In addition to that, the Ninth Malaysia Plan (2006-2010) and Tenth Malaysian Plan (2010-2015) designed policies and strategies to foster the involvement of women in business. Many programmes were created to enable women to obtain financial assistance to enhance their participation in business. Apart from that, women are also being highly encouraged to establish business network with organizations, both locally and internationally.

Since the importance of women entrepreneurship to the economy has been on the increase, a great deal of research into women entrepreneurs has concentrated on what motivates them to start their own business (Sarri and Trihopoulou, 2005). As much as creating the entrepreneurial minded women is important, a thorough study on what motivates them to start a business is also equally important. Most existing literature on Malaysian businesswomen has only focused on their roles, contributions, challenges and other social issues including entrepreneurial success in general (Zafir and Fazilah, 2011) and factors influencing their performance (Teoh and Chong, 2007) and many more which has been discovered with various limitation respectively.

Clearly, most studies on women entrepreneurship that focused on their entrepreneurial ventures has left more specific questions of their personality, environmental influences and what motivates them unanswered. Furthermore, the studies have been limited to a particular group of individuals and a comparison study of these factors in the developing economies are far and few between. It would be interesting to know if the personality, environmental influences and motivational factors differs for women entrepreneurs and women non-entrepreneurs.

Therefore, since entrepreneurship is an intentional process and an act of human decision, studies on personality will be able to explain the various characteristics of a particular individual. Motivation, on the other end, plays an important role in understanding the rationale of becoming entrepreneurs. Finally, studies on the environmental factors will be helpful in understanding the multivariate and complex phenomenon of entrepreneurship. There is a need to study these factors from an objective psychological standpoint, especially in Malaysia. Giving concentration on previous literatures, this paper, therefore, endeavors to address the attributes of personality, motivation and life situation antecedence of women entrepreneurs in small and medium scale industries in Malaysia with a comparison done on a group of women non entrepreneurs.

\section{Literature Review}

\subsection{The Concept of Entrepreneurship}

The word entrepreneur is believed to be originated from the French word entreprendre, which refers to individuals who undertake the risk of new venture. According to Hirsch and Peters (1989), the first to coin the term 'entrepreneur' was Richard Cantillon in 1755. Cantillon defined the entrepreneur as a person who invests, transforms and makes profit or loss. In other words, entrepreneurs' buys goods at a certain price, add value to the goods through transformation process, and then sells the goods at an uncertain price. An entrepreneur also undertakes whatever risks along the process.

The entrepreneurship research was originally developed by economists who focused the role of entrepreneur in economic growth and innovation (Brokhaus, 1988). According to Ray and Ramachandran (1996), early researchers in the field of entrepreneurship emerged from a variety of disciplines and backgrounds. Among them were the psychologists, anthropologists and sociologists who tried to understand the tendency in the study of entrepreneurship.The Schumpeterian theory distinguished the concept of business and entrepreneur. According to Schumpeter (1934), business is the implementation of new combinations of resources whereas the individual who carries out the implementation of the new combinations is the entrepreneur. The evolution of entrepreneurship became more interesting when he introduced the concept of creative destruction in 1934. He further defined entrepreneurship as a creative destruction force that sees the destruction of usual ways of doing things by the introduction of new improved ways.

Hagen (1971), from a sociological point of view explained entrepreneurship as 'withdrawal of status respect' which may occur when one or a few of the traditionally alike groups are displaced by force from their previous status by another traditional group. This results four kinds of responses based on the personality orientation of the individuals. They are the retreatist (people who works in the society but remain indifferent to his work and position), the ritualist (people who shows defensive behaviours and acts in the way accepted and approved in his society but with no hopes of improving his position), the reformist (people who are rebellious and attempts to establish a new society) and the innovator (people who are creative and who is likely to take up 
entrepreneurship). The innovator who takes up entrepreneurship is a creative problem solver who is interested in things and driven by a duty to achieve.

On the other end, Drucker (1985) defined different types of entrepreneurial initiatives based on the principles of innovation. The type of venture may have different focus which can be on knowledge, leadership, creative imitation, strategy to monopoly position with a specialty skill and many more. According to Silver (1983), entrepreneurs are people who learn special personal abilities, have special knowledge of technologies, processes, products, markets, systems and industries. They are also people who systematically think and act, recognize their own competence and limits as well as recognizes this in others. Further, entrepreneurs are found to be masters in managing information and their acting have significant impact on the economic, social, cultural and political scene.

\subsection{Women Entrepreneurs and the Influence of Environmental, Personality and Motivational Factors}

Studies recently found that more women are actively involved in business ventures. They are trying to become the trendsetters by deviating from the conventional, gender-specific roles and investing in businesses (Lai et al., 2010). Clearly, women entrepreneurs are emerging as more important and prominent than before. According to Verheul et al. (2006), the increase in female entrepreneurs is regarded as one of the important factor for economic development. Most self-employed women are considered capable at owning and managing up to one third of all businesses in developed countries (McClelland et al., 2005).

Environmental factors are found to be the significant predictors of whether an individual becomes an entrepreneur or manager (Kent et al. 1982). The experiences included demographic characteristics, formal education, post-secondary education, extra-curricular activities and pre-adult experiences. In another study, Cooper and Dunkelberg (1986) made a comparison between managers and entrepreneurs on family background, career paths, attitudes and motivations. The results of their study revealed that there is a substantial difference in their backgrounds, depending upon how they become owners and depending on their industry. Shapero and Sokol (1982) stated that the decision to start a new business involve the interaction between the individual and his socio economic environment. Family mentors, friends and previous work experiences all play an important role in deciding to become an entrepreneur. According to Ronstadt (1984), family considerations, time commitments and lack of role models are among the factors that could lead into becoming an entrepreneur. A study by Joanne Wilkens (1987) also indicates that a tradition of business in family is one of the most important motivators in tempting individuals to start their own enterprises.

Apart from environmental push, the personality factor is also positively associated with entrepreneurial decisions (Crant, 1993). A number of personality traits such as achievement, initiative, independence, risk taking, hard work and self-confidence have positively correlated with the desire to become entrepreneurs (Mathur \& Anamika, 1984). A study by Welsch and Young (1982) revealed that when entrepreneurs are compared with managers, there was a significant difference between personality traits and information sources. Entrepreneurs were found to have higher tolerance for ambiguity and top executives or middle managers. On the other hand, McClelland (1987) found that entrepreneurs were more proactive, anticipated events and felt they were able to influence the situation. Fagenson et al. (1991) identified that entrepreneurs have greater freedom with high level of excitement. They are able to be independent, very ambitious, creatively and demonstrate their capabilities beyond any bounds. Personal characteristics have been also identified as the intrinsic factors that are unique to a person's regular capacity to pursue any substantially gainful occupation. Most women engage in entrepreneurship to satisfy their personality needs like power, achievement, novel experiences and many more (Mohiuddin, 1983).

Apparently, a woman's decision to start-up a business does not usually originate from a single motivating cause. The motivation factors behind an entrepreneurial intention may be observed from various perspectives (Hanifa et.al, 2011; Barba \& Carlos, 2012). In general, most researchers found that the push factors such as independence, autonomy and family security added with pull factors such as job dissatisfaction or disappointments, boredom in previous workplace and family instability appear to be the main motives for women to venture into entrepreneurship (Shapero and Sokol, 1982; Hisrich and Brush, 1986; Sexton and Vesper, 1982; Buttner \& Moore, 1997; Hanifa, Yusuf \& Imad, 2011; Jose \& Joaquin, 2010; Lovely, Rahman \& Jia, 2012) According to Cole (1959), profit maximisation, security, prestige, power and social service were found to be potential motives in becoming an entrepreneur.

On the basis of above stated literature, it can be concluded that motivations, personality and environmental factors can influence women to become entrepreneurs. Studies on entrepreneurship so far examined these factors on a one to one basis but none combined all three to observe the intention to start-up businesses. 
Therefore, an empirical study on the combination of all these factors is believed to provide a new explanation into the field of entrepreneurship. More interestingly, this study aimed to identify the difference between motivation, personality and environmental factors among women entrepreneurs and non-entrepreneurs. The results will help to identify what is lacking among women non-entrepreneurs. Ultimately, the results would be helpful in designing appropriate programs and training to promote active entrepreneurship among women.

Based on the review of literature, Figure 1 shows a research model that has been developed for this study.

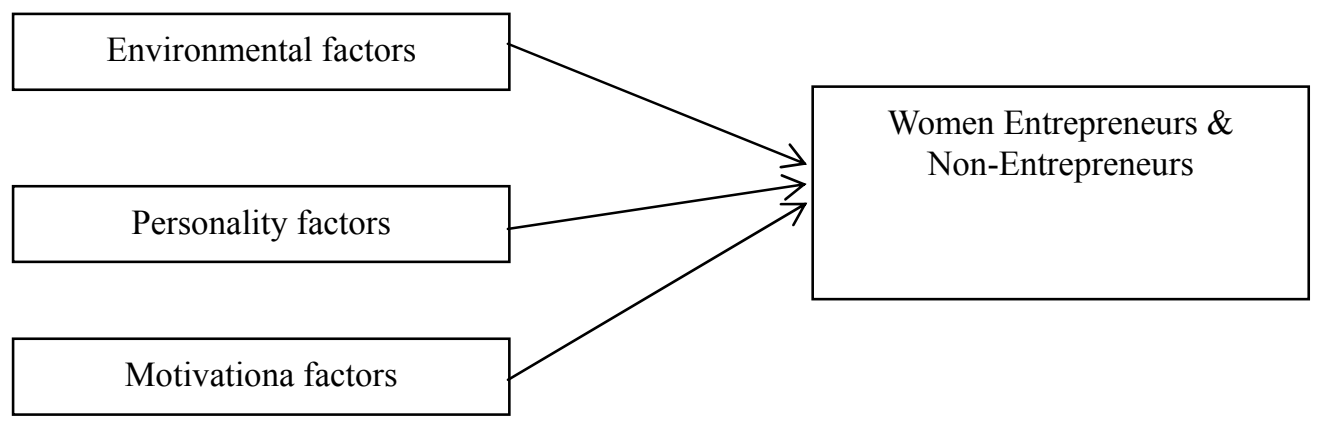

Figure 1. Research model

\section{Research Methodology}

\subsection{Population and Sampling Method}

Since this is a comparison study, the sample of this study comprises of women from two different categories. The population of women entrepreneurs for this study included all women entrepreneurs in the manufacturing and services sector registered under the Small and Medium Industries Development Corporation (SMIDEC). The second groups were women non-entrepreneurs, engaging in the administration and clerical department of various organizations. As for women entrepreneurs, a simple random sample was taken from each state listed as members in the SMIDEC's directory. The random selection of sample was done without replacement to avoid choosing any member of the population more than once. The samples were selected from the manufacturing, services and agricultural category. The women entrepreneurs from the three sectors were engaged in diverse business activities. In the manufacturing sector, the business ranged from manufacturing of food products, textiles, handicrafts, leather accessories, chemicals, industrial components and so on. In the services sector, women entrepreneurs were engaged in beauty or bridal parlours, spa centres, computer servicing, travel agencies and marketing research agencies. In the agricultural sector, the enterprises were based on crops, livestocs and fisheries.

On the other hand, the non-entrepreneurs consisted of employed women in banking and financial industries, higher learning institutions, insurance companies, private and public sectors. They are mainly from the administration and the clerical departments. The convenience sampling procedure focusing on snow balling technique was adopted as the sampling method for women non-entrepreneurs. Those women who fulfilled the selection criteria and who were willing to respond contributed to the research data. A total of two hundred and twenty five women entrepreneurs and two hundred and fifteen non-entrepreneurs participated in this study.

\subsection{Instrument Development}

The primary data were collected through mail survey using a self-administered questionnaire. This method was deemed most practical due to the geographically dispersed samples involved in this study. To answer the research questions developed, three main parts were used: (1) environmental, (2) personality factors, and (3) motivational factors. The questionnaire developed also included a section on demographic information. The Environmental factors and the Entrepreneurial Motivation Scale have been developed specifically for the purpose, the items for which were designed based on substantiation from previous research. The 16 Personality Factor scale that has been used to understand personality is an already established and standardised personality inventory which is highly reliable (Sunder 1996).

A total of 600 questionnaires were distributed to the respondents fulfilling the selection criteria (for women entrepreneurs). From the total, only 248 questionnaires were returned at the response rate of 41.3 percent. Finally, only 240 questionnaires were used as the remaining 8 were incomplete. Several data collection method 
such as postal and personal collection was employed based on the preference of the individual. SPSS 18.0 was used for data analysis.

\section{Result}

In order to empirically evaluate women entrepreneurs and non- entrepreneurs, a survey was conducted and a detailed profile of respondents is presented in Table 1.

Table 1. The profiles of respondents

\begin{tabular}{|c|c|c|c|c|}
\hline \multirow[t]{2}{*}{ Demographic } & \multicolumn{2}{|c|}{ Entrepreneurs } & \multicolumn{2}{|c|}{ Non Entrepreneurs } \\
\hline & Frequency & Percentage & Frequency & Percentage \\
\hline \multicolumn{5}{|l|}{ Age } \\
\hline $20-30$ & 50 & 22.2 & 83 & 38.5 \\
\hline $30-40$ & 77 & 34.2 & 97 & 45.1 \\
\hline $40-50$ & 63 & 28.0 & 35 & 16.3 \\
\hline$>50$ & 35 & 15.6 & 0 & 0 \\
\hline \multicolumn{5}{|l|}{ Race } \\
\hline Malay & 146 & 64.9 & 95 & 44.2 \\
\hline Chinese & 33 & 14.7 & 50 & 23.3 \\
\hline Indian & 46 & 20.4 & 49 & 22.8 \\
\hline Others & 0 & 0 & 21 & 9.8 \\
\hline \multicolumn{5}{|l|}{ Education } \\
\hline Masters & 24 & 10.7 & 0 & 0 \\
\hline Degree & 117 & 52 & 71 & 33 \\
\hline Diploma & 41 & 18.2 & 107 & 49.8 \\
\hline SPM & 43 & 19.1 & 37 & 17.2 \\
\hline \multicolumn{5}{|l|}{ Previous Working Experience } \\
\hline Yes & 199 & 88.4 & 164 & 76.3 \\
\hline No & 26 & 11.6 & 51 & 23.7 \\
\hline \multicolumn{5}{|l|}{ Childhood Background } \\
\hline City & 52 & 23.1 & 14 & 6.5 \\
\hline Town & 115 & 51.1 & 166 & 77.2 \\
\hline village & 58 & 25.8 & 35 & 16.3 \\
\hline \multicolumn{5}{|l|}{ Family Type } \\
\hline Nuclear & 126 & 56 & 181 & 84.2 \\
\hline Joint & 99 & 44 & 34 & 15.8 \\
\hline \multicolumn{5}{|l|}{ Monthly Income } \\
\hline$<\mathrm{RM} 2000$ & 19 & 8.4 & 23 & 10.7 \\
\hline RM2001-3000 & 48 & 21.3 & 101 & 47 \\
\hline RM3001-4000 & 71 & 31.6 & 61 & 28.4 \\
\hline RM4001-5000 & 43 & 19.1 & 30 & 14 \\
\hline$>$ RM5001 & 44 & 19.6 & 0 & 0 \\
\hline \multicolumn{5}{|l|}{ First Born } \\
\hline Yes & 65 & 28.9 & 109 & 49.3 \\
\hline No & 160 & 71.1 & 106 & 50.7 \\
\hline \multicolumn{5}{|l|}{ Number of Siblings } \\
\hline$<2$ & 31 & 13.8 & 21 & 9.8 \\
\hline $2-4$ & 118 & 52.4 & 162 & 75.3 \\
\hline $4-6$ & 52 & 23.1 & 32 & 14.9 \\
\hline$>6$ & 24 & 10.7 & 0 & 0 \\
\hline \multicolumn{5}{|l|}{ Marital Status } \\
\hline Married & 185 & 82.2 & 124 & 57.7 \\
\hline Unmarried & 40 & 17.8 & 91 & 42.3 \\
\hline
\end{tabular}

Based on the questionnaire survey, the profiles of the respondents are given in Table 1. The respondents are presented in two groups consisting of women entrepreneurs and women non-entrepreneurs. About 51 percent of respondents were women entrepreneurs and 49 percent were women non-entrepreneurs. In terms of age, the highest group for both entrepreneurs and non-entrepreneurs are between 30-40, which represents 34.2 percent and 45.1 percent respectively. Table 1 also indicates that 88.4 percent of women entrepreneurs and 76.3 percent of non-entrepreneurs has some previous working experience and most are from are from small towns. Majority 
of women entrepreneurs and non-entrepreneurs are from a nuclear type of family. Further, the monthly income of the respondents was gathered to understand the financial background. The highest number of women respondents (31.6 percent) earn between RM3000-RM4000. As for non-entrepreneurs, 47.0 percent earns between RM2000-RM3000. In terms of birth order, 28.9 percent of women entrepreneurs are first born while for non-entrepreneurs, 49.3 percent are the first born. The respondent's profile also shows that 82.2 and 57.7 percent of women entrepreneurs and non-entrepreneurs are married respectively.

Table 2. Logistic regression analysis upon environmentall factors

\begin{tabular}{lcccc}
\hline \multirow{2}{*}{ Model } & Model Fitting Criteria & \multicolumn{2}{c}{ Likelihood Ratio Tests } \\
\cline { 2 - 5 } & -2 Log Likelihood & Chi-Square & Df & Sig. \\
\hline Intercept & 571.578 & & & \\
Final & 216.432 & 355.146 & 5 & $<0.001$ \\
\hline
\end{tabular}

Table 3. Likelihood ratio tests environmental factors

\begin{tabular}{lcccc}
\hline \multirow{2}{*}{ Effect } & Model Fitting Criteria & \multicolumn{3}{c}{ Likelihood Ratio Tests } \\
\cline { 2 - 5 } & -2Log Likelihood of Reduced Model & Chi-Square & Df & Sig. \\
\hline Intercept & 442.229 & 225.798 & 1 & $<0.001$ \\
Psychological support & 224.451 & 8.019 & 1 & 0.005 \\
Benefit from environment & 221.232 & 4.800 & 1 & 0.028 \\
Previous work condition & 229.685 & 13.253 & 1 & $<0.001$ \\
Financial status & 217.917 & 1.485 & 1 & 0.223 \\
Competence & 216.627 & 0.195 & 1 & 0.659 \\
\hline
\end{tabular}

The environmental factors are psychological support, benefit from environment, previous work condition, financial status and competence. The results are provided in Tables 2 and Table 3. The p-value in Table 2 is less than 0.001 . Thus, at least one of the life situational factors can be used to predict women entreprenuership. In Table 3, out of the five predictors, only psychological support, benefit from environment, and previous work condition are significant predictors of women entreprenuership.

Table 4. Model fitting information for motivational factors

\begin{tabular}{lcccc}
\hline \multirow{2}{*}{ Model } & Model Fitting Criteria & \multicolumn{2}{c}{ Likelihood Ratio Tests } \\
\cline { 2 - 5 } & -2 Log Likelihood & Chi-Square & Df & Sig. \\
\hline Intercept & 564.871 & & & \\
Final & 454.257 & 110.614 & 5 & $<0.001$ \\
\hline
\end{tabular}

Table 5. Likelihood ratio tests for motivational factors

\begin{tabular}{ccccc}
\hline \multirow{2}{*}{ Effect } & Model Fitting Criteria & \multicolumn{3}{c}{ Likelihood Ratio Tests } \\
\cline { 2 - 5 } & -2Log Likelihood of Reduced Model & Chi-Square & Df & Sig. \\
\hline Intercept & 501.544 & 47.287 & 1 & .000 \\
Entrepreneurial core & 490.932 & 36.675 & 1 & .000 \\
Work core & 492.061 & 37.804 & 1 & .000 \\
Social core & 459.832 & 5.575 & 1 & .018 \\
Individual core & 457.612 & 3.355 & 1 & .067 \\
Economic core & 459.276 & 5.019 & 1 & .025 \\
\hline
\end{tabular}

The motivational factors were entrepreneurial core, work core, social core, individual core and economic core. The results are provided in Tables 4 and Table 5. The p-value in Table 4 is less than 0.001 . Thus, at least one of the motivational factors can be used to predict women entreprenuership.In Table 5 out of the five predictors, individual core is not a significant predictor of women entreprenuership. 
Table 6. Model fitting information for personality attributes

\begin{tabular}{|c|c|c|c|c|}
\hline \multirow{2}{*}{ Model } & \multirow{2}{*}{$\begin{array}{c}\text { Model Fitting Criteria } \\
\text {-2Log Likelihood }\end{array}$} & \multicolumn{3}{|c|}{ Likelihood Ratio Tests } \\
\hline & & Chi-Square & Df & Sig. \\
\hline Intercept & 602.575 & & & \\
\hline Final & 360.117 & 242.458 & 16 & $<0.001$ \\
\hline
\end{tabular}

Table 7. Model fitting information for personality attributes

\begin{tabular}{lcccc}
\hline \multirow{2}{*}{ Effect } & Model Fitting Criteria & \multicolumn{3}{c}{ Likelihood Ratio Tests } \\
\cline { 2 - 5 } & -2Log Likelihood of Reduced Model & Chi-Square & Df & Sig. \\
\hline Intercept & 365.597 & 5.480 & 1 & .019 \\
Warmth & 363.536 & 3.418 & 1 & .064 \\
Reasoning & 369.925 & 9.807 & 1 & .002 \\
Emotional Stability & 376.050 & 15.932 & 1 & .000 \\
Dominance & 363.112 & 2.994 & 1 & .084 \\
Liveliness & 365.326 & 5.209 & 1 & .022 \\
Rule-Consciousness & 363.742 & 3.624 & 1 & .057 \\
Social Boldness & 362.475 & 2.358 & 1 & .125 \\
Sensitivity & 360.753 & .635 & 1 & .426 \\
Vigilance & 364.338 & 4.220 & 1 & .040 \\
Abstractedness & 369.247 & 9.130 & 1 & .003 \\
Privateness & 378.830 & 18.713 & 1 & .000 \\
Apprehension & 360.999 & .882 & 1 & .348 \\
Openness to Change & 375.649 & 15.532 & 1 & .000 \\
Self-Reliance & 360.246 & .129 & 1 & .720 \\
Perfectionism & 378.098 & 17.981 & 1 & .000 \\
Tension & 382.836 & 22.718 & 1 & .000 \\
\hline
\end{tabular}

The personality attributes were Warmth, Reasoning, Emotional Stability, Dominance, Liveliness, Rule-Consciousness, Social, Boldness, Sensitivity, Vigilance, Abstractedness, Privateness, Apprehension, Openness to Change, Self-Reliance, Perfectionism and Tension. The results are provided in Tables 6 and Table 7. The p-value in Table 6 is less than 0.001. Thus, at least one of the personality attributes can be used to predict women entreprenuership. In Table 7, out of the 16 predictors, only Reasoning, Emotional stability, Liveliness, Vigilance, Abstractness, Privateness, Openness to change, Perfectionism and Tension are the significant predictor of women entreprenuership.

\section{Discussion}

This study has attempted an empirical approach in understanding women entrepreneurs by comparing them with non-entrepreneurs and also comparing women entrepreneurs of three different sectors. The results of this study reveal that environmental factors, personality and motivation variables contribute significantly to the entrepreneurial intention in women. The dimensions of such as psychological support, benefit from environment and previous work condition emerge as significant environmentall factors. The results show that the entrepreneurs have had lower psychological support than the non-entrepreneurs. This result seems to support certain observations by researchers that stress that entrepreneurs hail from difficult family backgrounds (Silver, 1983; Wilkens, 1987).

According to Stevenson (1992), entrepreneurs are known to be very skilled in their capacity to utilize the resources optimally. Ironically, this study also revealed that entrepreneurs have been able to make use of the opportunities by gaining a better benefit from the environment. On the other end, studies by Sharma (1979), Brockhous (1988) and Anna (1990) support the observation that the previous work condition acts as a push factor in entrepreneurship. Apparently, when entrepreneurs are stressed or dissatisfied with their work condition, they tend to escape by venturing into entrepreneurship. In this study, the entrepreneurs have been found to have a poorer working condition.

The nine significant personality differences observed in this study are that the entrepreneurs portray more reasoning skills, emotional stability, vigilance and abstractness. Apart from that, entrepreneurs are also found to have more privateness, high openness to change, perfectionism, more tension and less liveliness. These findings 
are consistent with Vries (1996) who revealed that entrepreneurs are people with need of control, sense of distrust, desire for applause and the need to resort primitive defense mechanisms.

The results of this study also show that entrepreneurship is taken up by women when they experience some stress factors. Stevenson (1995) observed that the struggle for recognition had characterized the lives of women entrepreneurs before the business start-up. The independence, control and strong sense of doing things on their own were the major satisfactions or rewards that these women gained by venturing into business. Owning a business helped them to regain the lost self-esteem and to develop greater self-confidence.

\section{Conclusion and Implications}

Many scholars have highlighted the role of entrepreneurs in the economic prosperity as many countries are reaping the fruits of this venture (Muhammad, Naveed \& Sarfraz, 2011). Notably, women entrepreneurship has been gaining credence as an important activity contributing to the national economy. Psychological research in entrepreneurship has made attempts to understand the entrepreneurial personality. The trait approaches that were adopted have been able to identify certain strong personal qualities of entrepreneurs but an emphatic conclusion on the entrepreneurial personality has not evolved so far (Gartner, 1988). However, as entrepreneurial activities originate from individuals, a nominal understanding of their personality traits with their skills and respective background is crucial for the development of a comprehensive theory (Ray and Ramachandran, 1996).

Apart from personality studies, motivation factors play an important role in developing entrepreneurs. According to Hisrich (1986), women entrepreneurs possess very different motivations compared to their male counterparts. Thus, the need to determine the motivational basis in women entrepreneurs is also crucial. Many studies also suggest that certain environmental factors and life experiences could lead to entrepreneurship. This being an exploratory study, an understanding of the environmental attributes that may be contributing to women was felt to be very important. The results of this study have been able to empirically provide evidence to the hypothesis that entrepreneurs are different from non-entrepreneurs and that significant difference exist between entrepreneurs in different types of ventures.

\section{References}

Anna, V. (1990). Socio-economic basis of women of entrepreneuship. SEDME, 1, 17-47.

Barba-Sánchez, V., \& Atienza-Sahuquillo, C. (2012). Entrepreneurial Behavior: Impact of Motivation Factors on Decision to Create a New Venture. IEDEE, 18(2), 132-138.

Bolton, J. (1971). Small Firms: Report of the commission of Inquart on Small Firms. HMSO.

Brockhaus, R. (1988). Entrepreneurship Research: Are We Playing The Correct Game? American Journal of Small Business, 12, 55-61.

Cole, A. (1959). Business Entreprise In Its Social Setting. Cambridge: Harvard University Press.

Cooper, A., William, C., \& Dunkelberg. (1986). Entrepreneurship and Paths to Business Ownership. Strategic Management Journal, 7, 53-68. http://dx.doi.org/10.1002/smj.4250070106

Cooper, D. R., \& Schindler, P. S. (2003). Business Research Method. New York: McGraw-Hill.

Drucker, P. (1985). Innovation and entrepreneurship. Harper and Row.

Fagenson, A. E., \& Eric, C. M. (1991). Perceptions Of The Sex-Role Stereotypic Characteristics Of Entrepreneurs: Women's Evaluation. Entrepreneurship Theory and Practice, 15, 174-186.

Hanifa, I., Yusuf, M., \& Sidani, I. B. (2011). United Arab Emirates female entrepreneurs: motivations and frustrations. Equality, Diversity and Inclusion: An International Journal, 30(5), 409-424. http://dx.doi.org/10.1108/02610151111150654

Hisrich, R. D., \& Peters, M. P. (1989). Entrepreneurship: Starting, Developing and Managing a New Enterprise. Homewood Illionis.

Hofer, W., \& Bygrave, W. (1992). Theorising about entrepreneurship. Entrepreneurship Theory and Practice, Winter, 13-22.

Jose, M. C., \& Joaquín, L. (2010). The influence of variables of attitude on collective entrepreneurship. International Entrepreneurship and Management Journal, 6(1), 23-38. http://dx.doi.org/10.1007/s11365-009-0131-6

Kent, C. A., Sexton, D. L., \& Vesper, K. H. (1982). Encyclopedia Of Entrepreneurship. Eaglewood Cliffs, Prentice Hall, New Jersey. 
Ket De Vries, F. R. (1996). The anatomy of the entrepreneur: Clinical observations. Human Relations, 49, 853-883. http://dx.doi.org/10.1177/001872679604900701

Kidane, A., \& Harvey, B. H. (2009). Profile of entrepreneurs: Employing stepwise regression analysis to determine factors that impact success of entrepreneurs. Review of Business Research, 9(3), 55-65.

Lovely, P., Jia, J. R., \& Wakilur Rahman, M. (2012). Women entrepreneurship development in Bangladesh: What are the challenges ahead? African Journal of Business Management, 6(11), 3862-3871.

Mathur, P., \& Anamika. (1987). Difference of personality traits among male and female successful entrepreneurs. 29th Annual conference of Indian Academy of Applied Psychology (pp. 23-25). Waltair.

McClelland, D. C. (1987). Characteristics of successful entrepreneurs. Journal of Creative Behaviour, 21, 219-233. http://dx.doi.org/10.1002/j.2162-6057.1987.tb00479.x

Mohiuddin, A. (1983). Entrepreneurship Development among Women-Retrospect and Prospects. SEDME, 10, $15-22$.

Myra, H. M., Stevenson, H. H., \& Dial, J. (1995). Entrepreneurship: A definition revisited. Frontiers of Entrepreneurship Research. Massachusetts: Babson College Centre for entrepreneurial studies.

Nafukho, F. M., \& Helen Muyia, M. A. (2010). Entrepreneurship and socioeconomic development in Africa: a reality or myth? Journal of European Industrail Training, 34(2), 96-109. http://dx.doi.org/10.1108/03090591011023961

Normah, M. A. (2006). SMEs: Building Blocks for Economic Growth. National Statistics Conference. Department of Statistics, Malaysia. $\quad$ Retrieved from http://www.digitallibrary.my/dmdocuments/malaysiakini/266_22Hjh_Normah.pdf

Ray \& Ramachandran. (1996). Towards a framework for a comprehensive theory of entrepreneurship. The Journal of Entrepreneruship, 1, 4-22.

Ronstadt, R. (1984). Ex-entrepreneurs and the decision to start an entrepreneurial career. In F. T. J. A. Hornaday (Ed.), Fromtiers of Entrepreneurship Research (pp. 437-460). Wellesley: MA, Babson College.

Sarri, K., \& Trihopoulou, A. (2005). Female Entrepreneurs' Personal Characteristics And Motivation: A Review Of The Greek Situation. Women In Management Review, 20(1), 24-36. http://dx.doi.org/10.1108/09649420510579559

Schumpeter, J. A. (1934). Theory of Economic Development. Cambridge: Harvard University press.

Shapero, A., \& Sokol, L. (1982). The social dimension of entrepreneurship. In C. A. Dent (Ed.), Encyclopaedia of entrepreneurship. Englewood Cliffs, NJ: Prentice Hall.

Sharma, S. (1979). Small Entrepreneurial Development in Some Asian Countries: A Comparative Study. New Delhi: Life and Light.

Silver, D. A. (1983). The Entrepreneurial Life: How To Go For It And Get It. New York: John Wiley \& Sons.

Stevenson, A. (1992). Contemporary Entrepreneurship: Towards a female paradigm. Frontiers of Entrepreneurship Research (pp. 530-531). Wellesley: Babson College.

Sunder, D. L. (1996). A study of entrepreneurial personality. Unpublished Dissertation, Indian Institute of Technology, Madras, India

Teoh, W. \& Chong, S. C. (n. d.). Theorising a framework of factors influencing performance of women entrepreneurs in Malaysia. Retrieved from http://www.asiaentrepreneurshipjournal.com/AJESIII2Teoh.pdf

Welsch, H., \& Young, E. (1982). Comparative Analysis of Male And Female Entrepreneurs With Respect To Personality Characteristics, Small Business Problems And Information Source Preferences. Proceedings International Council for Small Business, 2-10.

Wilkens, J. (1987). Her own business: Success secrets of entrepreneurial women. US: McGraw Hill.

Zafir, M. M., \& Fazilah, M. H. (2011). Entrepreneurial success: An exploratory study among entrepreneurs. International Journal of Business and Management, 6(1).

\section{Copyrights}

Copyright for this article is retained by the author(s), with first publication rights granted to the journal.

This is an open-access article distributed under the terms and conditions of the Creative Commons Attribution license (http://creativecommons.org/licenses/by/3.0/). 